\title{
Gender, Subjectivity and Agency: A Study of Workers in Noida Export Processing Zone, India
}

\author{
Urvashi Soni-Sinha \\ McMaster University, Canada
}

\begin{abstract}
The paper analyses the discursive construction of the gender division of labour in machinemade jewellery production in the Noida Export Processing Zone (NEPZ), India. It examines the construction of gendered subjectivities of women and men in investing in the discourses about their work. Men constitute their masculine subjectivities by investing in the discourses around their work in master making, casting, and polishing as 'skilled' and 'tough'. Women's subjectivities are fragmented in that though they invest in the discourses constructing their work in wax and quality control sections as 'light', requiring 'eye for detail' and 'patience', they present disruption to the construction of their work and their identities as 'unskilled'. By challenging their discursive construction as 'unskilled' they negotiate and interrupt the power structures or what Ong (1991: 297) calls 'expand the space of political struggle in their everyday lives'.
\end{abstract}

KEY WORDS: agency, discourse, gender division of labour, India, subjectivity

\section{Introduction}

The Noida Export Processing Zone, one of seven export processing zones (EPZs) in India was set up in 1985 in the Gautam Buddha Nagar (earlier called Ghaziabad) district of Uttar Pradesh. Gems and jewellery exports constituted the largest share at 33 percent of aggregate exports in 1996. This paper uses discourse analysis to understand the gendered production and labour process of machinemade jewellery production in NEPZ. Men constitute their masculine identities by investing in the discourses around their work in master making, casting, and polishing as 'skilled' and 'tough'. The subjectivities of women workers are constituted through the complex and fluid investments in discourses which construct their work in quality control and wax sections as 'light' and requiring 'eye for detail'. Though the women workers are interpellated into the production process as 'unskilled' and 'docile' workers they do not always acclaim this position and present several instances that challenge this discursive positioning, thus presenting a fragmented subjectivity. In questioning their constitution as 'secondary workers' women challenge the naturalized gendered and racialized hierarchies embedded in the globalized processes of which NEPZ is a part. 


\section{Gendered Employment in World Market Factories}

In the 1960s and 1970s, multinationals were crucial in creating the new international division of labour as some manufacturing operations were transferred from particular high-cost developed countries to particular low-cost developing countries (Frobel, Heinrichs and Kreye 1980). Much of the literature relating to EPZs in South East Asia and Latin America in the 80s and early 90s noted a majority presence of young, unmarried women in these zones, who were the preferred work force as they are seen by employers as being available at low wages, submissive, naturally dexterous and disposable (Frobel, Heinrichs and Kreye 1980; Grossman 1980; Elson and Pearson 1981; Safa 1981; Chapkis and Enloe 1983; Fuentes and Ehrenreich 1984; Women Working World-Wide 1991). Most of this feminist literature on the new international division of labour was inspired by Marxist-feminist thinking and argued that the oppression of women was functional to capitalism.

Several researchers more recently have argued that expansion of trade with developed countries contributes to a rise in women's employment in developing countries by raising the demand for women workers in the manufacturing sector (Joekes 1987, 1995; Standing 1989, 1999; Lim 1990; Pearson 1991; Ozler 2000; Braunstein 2006). Some studies note a shift towards a decline in the employment of women in EPZs due to the changing characteristics of export firms such as their greater capital intensity (Joekes and Weston 1994; Joekes 1995; ILO 2002), whereas others (Christa Wichterich 2000) indicate the preponderance of women at the end of the production chain with the spread of the global conveyor belt across different countries and growth of outsourcing.

Some of these studies link the high demand for women workers in export production to their 'low skills' required in labour intensive export production (Joekes 1987; Pearson 1991). Other studies (Standing 1989; Pearson 1991; Braunstein 2006) link the increase in demand for women in export production to the constitution of women as cheaper labour source and the pressure on export companies to reduce costs. Radhika Balakrishnan and Asad Sayeed (2002) note that the push towards subcontracting in Asia is initiated by a need to reduce labour costs and that a high percentage of women are employed in low-skilled subcontracted work located in small shops and at home. Besides, skill requirements and cost of production gender stereotyping of women as docile workers by employers emerges as another important reason for their preference. Pyle and Ward, (2003: 462) describe the growth of exports with globalization as one of the 'gendered global production networks'. They note 'Many multinational corporations (MNCs) prefer low-cost women workers, who they believe are unlikely to resist adverse conditions - an example of MNCs using the social construction of gender to their advantage' (ibid: 467). Salzinger (2003) demonstrates how productive femininities are not pregiven but are produced on the shopfloor.

The notion of an 'always-already' docile, dextrous, and cheap woman, that is, of a potential worker whose productive femininity requires not creation but recognition, is thus a transnationally produced fantasy with consequences, for it is precisely within these gendered discourses that decisions about production are made and shopfloor subjectswhether productive or resistant-are constituted. (ibid:10) 
Caraway (2005) has argued how gendered discourses of work bring about gendered transformations with changes in the industrial policy and lead to feminization of the labour force.

'Docility' and 'dispensability' as explanations for the preponderance of women in the export oriented industries (Elson and Pearson 1981; Elson 1983; Fuentes and Ehrenreich 1983) contradict the evidence of militancy and activism of women in trade unions in Thailand (Porpora, Lim and Prommas 1989: 271), in South Korean export factories (Oh 1983; Sun 1987), in the Mexican maquiladoras (Salzinger 2003) and in the Chinese garment industry (Chan, 2006). On the other hand women in Malaysian export processing zones have used mass hysteria as a culturally sanctioned phenomenon to resist labour discipline and male control (Ong 1987). Women also show their agency by using gendered and racial ideologies as resources to use the logic of the managers against themselves in the Silicon Valley (Hossfeld 1990).

A review of the studies on the gendered nature of EOIs and EPZs in India (Banerjee 1983, 1991; Sharma and Sengupta 1984; Rao and Husain 1991; Kalpagam 1994) suggests that most of these are descriptive in nature and stress the empirical details of women's employment in the EOIs. These studies note a clear gender division of labour where men are constructed as skilled and are better paid and women are constructed as unskilled and cheap. Some Indian studies mention docility and ease of controlling women as important reasons for hiring women (Banerjee 1983; Rao and Husain 1991). However, Kalpagam's (1994: 177-185) study of the garment export industry in Madras reveals a significant representation of women in trade unions, which questions the generalized assumption of women as docile.

Some Third World feminist thinkers (Ong 1988; Mohanty 1991;) have criticized the meta-narratives of liberal and Marxist feminist writers for their construction of Third World women as uniformly subjugated by patriarchy and lacking any agency. Mohanty (2003: 509) emphasizes the need to link political economy and culture in any form of feminist theorizing. Ong (1991: 280) notes that workers' struggle and resistances are often not based upon class interests and may be individual or covert in nature. According to Ong (ibid: 281) '...the daily practices of workers in defending themselves against various modes of control are also struggles over cultural meanings, values and goals. These cultural values are shaped, contested and defended in different domains of power relations.'

Jane L. Parpart (1993: 454), while commending socialist feminist perceptivity to gender and class, has criticized it for paying scant attention to ideology in a materialist analysis and for its inability to investigate the construction of meaning and its dissemination through language. She highlights the need to enrich socialist feminist analysis by adding on the postmodern feminist analysis of discourse, knowledge/power relations, and difference. Drawing on these critiques, I seek to examine the processes by which jobs in the machinemade jewellery sector in India are gendered as masculine or feminine, constructing the subjectivities of men as 'skilled' and of women as 'unskilled' and the contestations of women to their interpellations as 'unskilled'. I use an eclectic approach that combines the insights of postmodernism and Marxism. This approach allows me to understand the localized contexts of women's and men's lives, while recognizing the greater structural patterns of power, in relation to jewellery 
production. McLaughlin (1999) has succinctly argued for a case of combining the cultural studies and political economy debates in feminist analysis which goes beyond the 'separate sphere argument'. Thus according to McLaughin (ibid: 330) '...feminists need an approach that retains cultural studies' awareness of 'politics of representing the other' while foregrounding the political economic realities that enable and deny access to the means of representation.' Thus, combining the insights of Marxism and postmodernism in my study enables a better understanding of the dialectical relationship between structure and agency.

Postmodern analysis is especially useful in emphasizing the agency of the subject and in its recognition of manifold structures of power. Canning (1994: 377) uses the concept of agency to analyze how discourse changes, how subjects contest power in its discursive form and how their desires and discontents transform discursive systems. Butler's (1995: 135) insight on agency as resignification is very useful here:

...if the subject is a reworking of the very discursive processes by which it is worked, then 'agency' is to be found in the possibilities of resignification opened up by discourse. In this sense, discourse is the horizon of agency, but also, performativity is to be rethought as resignification. (Butler, 1995: 135)

In the context of my study, I find several instances when women workers while performing 'women's jobs' as in the wax and the quality control sections, resignify it as requiring special skills not possessed by men, thus contesting the power structures.

A concept related to agency is identity. Andermahr, Lovell and Wolkowitz (1997: 124125) distinguish between identity as socially constructed and identity as a social process. They argue that identity may be best considered alongside its binary partner 'difference' and that while the differences across which people might construct identities are unlimited, a few recur across all cultures including differentiation by sex. Butler (1996: 381) when commenting on the contingent nature of gendered subject formation which is constituted by performativity and whose identity is not seamless writes 'If there is, as it were, always a compulsion to repeat, repetition never fully accomplishes identity. That there is a need for a repetition at all is a sign that identity is not self identical.'

Work plays an important role in shaping the identity of men. Studies by Ford (1985) and Ingham (1984) indicate the centrality of paid work in the lives of men. Masculine identity is socially constructed through paid work, which is embedded in an occupation and often within an organization (Cheng 1996: xiv). Cockburn (1983: 133) has studied the differences between skilled and unskilled workers and the ways in which work is identified with masculinity. Game and Pringle (1983: 28-29) shed useful light on the polarities at work like skilled/unskilled, heavy/light, dangerous/less dangerous, dirty/clean, interesting/boring and mobile/immobile, with the former being associated with men and the latter with women. Wilkinson-Weber (1997) in her study of chikan garment industry of Lucknow, India describes how homeworking women embroiders are culturally constructed as 'unskilled' and their wage work described as 'spare-time work'. This is in contrast to the historical description of the male artisans involved in chikan 
work a century ago as 'professional' (ibid: 53). These have parallels with my study where Cartesian logic is used by management to construct men's work as 'tough' and 'skilled' and women's work as 'delicate' and 'unskilled', thus producing masculine men and feminine women.

According to Foucault (1979) subjectivity is not autonomous and independent from structural forces. Rather, subjectivity is itself constituted by 'disciplinary practices' and 'relations of power'. According to Collinson (1992: 29-30) human subjectivity is always characterized by a dual experience of self as both separate from, yet also related to, the natural and social world. The dual experience of self as both subject and object creates an ambiguity at the very core of subjectivity, which is irreducible, but also often contradictory. Ram (1991) in her ethnographic study of Mukkuvar people in India analyses conflicting cultural constructs of women as imbued with 'good' versus 'evil' femininity which leads women to enter into the labour process with contradictory gender specific subjectivity. In my case study I find that some women accept the gender division of labour (GDL) but question the construction of their work as unskilled while others contest the reinforcement of the gender division of labour on the shop-floor. The societal construction of their role as homemakers contradicts their lived experience of long hours of paid work. Several women recognize the importance of their wages to household budgeting and question their construction as 'cheap' and secondary workers.

Henriques et al (1984) make a valuable contribution through use of Lacanian psychoanalysis and Foucauldian theories of disciplinary power and resistance, to reconstruct a subject which is multiple, fragmentary and discontinuous. They focus on the ways in which individuals 'invest' in prevailing discourses and discursive practices to reproduce their gendered subjectivities. Kondo's study of part-time women workers in Japan indicates multilayered discourses, which construct the gendered work identities of women. Kondo (1990: 299) concludes "...words like "resistance" and "accommodation" are inadequate, for apparent resistance is constantly mitigated by collusion, and accommodation may have unexpectedly subversive effects.'

Salzinger (2000: 86) in her study of a maquladora plant, indicates that 'the most effective forms of labour control are interpellatory structures in which productive subjectivities are evoked within daily shopfloor interactions'. She argues that women are rendered cheap, docile and dexterous through sexualized labour control which interpellates them as 'sexual objects' and 'productive subjects' (ibid: 87). Salzinger (2003: 16-17) makes a similar argument in her book where she argues that docility and productivity are produced in the women workers by transnational companies in places like Mexico via interpellation as a primary mechanism of workplace control. In the context of my study I would argue that the productive subjectivities of women are split and discontinuous, such that several of them question their interpellation as 'unskilled' while investing in their work in wax and quality control as requiring women's traits.

\section{The Research Process}

This paper, which is part of a larger study on jewellery production in India, is based on nine months of field study in 1996-97 and a follow up of two months in 1998. The focus of this 
paper is on the six machinemade jewellery companies in Noida Export Processing Zone (NEPZ). The study involved questionnaire survey on the six companies. The questionnaire survey was aimed to discern the ownership type of the units, the nature of jewellery produced, the company policy on recruitment, the gender composition and demographic profile of the work force and the skill categorisation of workers by gender. Semi-structured interviews were held with five men and one woman entrepreneur and with twenty-two women and nine men workers in the factory premises of machinemade production units in the zone. Follow up visits were made to thirteen women and one man, at their homes. Contacts were made with six new informants - five women and one man - in the neighbourhood of other workers or related to the workers who were contacted at home; so that I interviewed thirty seven workers in total. Non participant observation of the different factories comprises an important part of the study. All names of the companies and respondents are pseudonyms.

In the course of negotiating access with the entrepreneurs in the zone I had to hide my positionality as a feminist and highlight my background as an economist interested in a gendered perspective on employment. ${ }^{1}$ There is a reversal of the power axis here as it was the researched that were all powerful as I was repeatedly told by the entrepreneurs/managers to come later and in many cases the agreed appointment time and even dates were not kept by them.

However, access through the entrepreneurs positioned me as an 'outsider' to the workers. Getting access through the managers and interviewing workers in their work hours meant that there was little scope for informal conversation and reducing the implicit power differential between the workers and me during my first meeting with them in the factory premises. Lal (1996) notes in the context of her ethnographic research in the electronic and textile factories in Delhi:

The research situation often places the researcher in an overly powerful position vis-à-vis research subjects and this inequality is exacerbated by the researcher's often necessary relationship with access providers who may have control over other research subjects. (ibid: 196).

Nonetheless, I tried to build the confidence of the women and men workers about the purpose of my research, alleviating the fears of some that it would have a negative effect on their job or lives. All the interviews with the workers were carried out in Hindi and all except two were tape recorded, and later translated and transcribed by me. My being Indian and a woman did play a crucial role in developing empathy with the women respondents. However, positional sameness and difference with my respondents did not work in a linear fashion and nor did the relationship remain the same in the course of the research. It was in my follow up visits to my respondents' residences that they developed the most confidence in me and were the most open about their experiences in the factories and home.

My talks with my respondents at their homes were in the nature of 'structured conversations', which lasted between one and two hours. All of these interviews were recorded. It was here that in depth information about different company policies and the many overt and covert ways in which women resisted the control of the management was revealed. There were 
many instances when I felt an 'insider', our shared identities as women and Indian making my class difference seem insignificant to me. These were instances when I seemed to have been in Spivak's (1990: 42) words successful in not only listening to the other constituency but learning to speak in a way so as to be taken seriously by my respondents. Several women would freely vent their anger towards the managers but later express their worry that it might have an adverse impact on them. For example Sunayna, when describing her dissatisfaction and sense of being exploited in the company, said:

All are the same, they make us slog and they do not want to pay us. Sometimes I feel so angry that I would leave my job tomorrow. I will lose my vision and also my thinking here. There is so much thinking involved in this work. The manager does not have any brain of his own.

However, after about an hour and a half she suddenly began expressing a deep concern that her critique should not be conveyed to the managers. Her fear was allayed after my reassurance. Thus different aspects of my multiple positionality - as Indian, as woman, as from a middle class elite background - took primacy at different times in my interaction with respondents.

\section{A Profile of Machinemade Jewellery}

\section{THE PRODUCTION PROCESS}

According to Burawoy (1985) a factory regime comprises both the labour process and the political and ideological apparatuses of production. He argues that in capitalist labour relations the character of these factory regimes has shifted from despotic to hegemonic and finally to despotic hegemonic. In my case study I find elements of the three regimes coexisting in a gendered terrain of different factories and diversity in the extent of labour protection across firms. However, there were no unions prevalent in any factory and a widespread non-compliance of labour laws with the covert connivance of the State machinery which propagated liberalization and growth of the global factories.

Machinemade jewellery production is different from handmade jewellery production in its scale and in its use of machines. The economies of scale in machinemade jewellery production arise with the replication of a masterpiece made in silver or a base metal.

The masterpieces form the basis of the mass production of the pieces in gold. There is an overlap between machinemade and handmade jewellery production in that the masterpiece is made by hand by men artisans who in many cases have moved from handmade to machinemade jewellery production. Master making is considered the most 'skilled' job, and is organized as a separate section in the factory, all the master makers sitting and working together. The payment of master makers by piece ensures labour control and productivity.

The masterpiece made in silver or base metal is then cast in wax, as a first stage in the process of obtaining a large number of gold or silver pieces similar to the master. First the master 
is placed between two pieces of rubber and vulcanised. Vulcanisation involves heating the rubber at high pressure and temperature. After that the rubber, which is now sealed, is cut into two halves with a sharp knife, the master is removed and the pattern of the master remains as a cavity in the rubber. Next the rubber mould is held between two pieces of aluminium and pressed against the wax injector. The wax injector contains molten wax at seventy to eighty degrees centigrade, depending on the quality of the wax. High-pressure air forces the wax into the cavity, where it takes the shape of the masterpiece. The wax pieces are then cleaned, and depending on the size of the piece, between fifty to a hundred pieces are soldered on to an iron stand to form a tree shape. The wax department has a preponderance of women workers who do wax injection and cleaning. There are a small number of men workers here who are involved in mould cutting. Labour control is exercised primarily through male 'super-vision'. Several companies made the women workers sign on target production sheets in the wax department. According to Aditi, who did wax cleaning:

Yes, we had to sign on the paper saying that we meet a target of 500 pieces. But what can I do, I might be able to make 400 or 450 pieces but not 500. Sometimes I do make 500 pieces. The target for women doing injection is 1000 and for us involved in cleaning, the target is 500. If the pieces are small and it is a pendent, I can even make 600 or 700 . But if the pieces are big and intricate then it is difficult. Sometimes the ring pieces and the pendent are equally difficult.

After a tree of wax casts has been made, casting in gold or silver takes place. This process of gold/silver casting is carried out by men workers in a separate section of the factory, and labour control is exercised through direct management supervision. Casting is done in the vacuum machine where a metal flask is put over the wax tree and some plaster is added to the flask along with distilled water. The flask rotates and the mixture of plaster and distilled water sets at room temperature. This process is called the investment cycle. Next the flask is put inside a furnace where the wax will slowly melt and collect in the tray, and then burn out in a ten to twelve hour cycle, different temperatures being set by a programmer. The temperature in the furnace can vary between 280-730 degrees centigrade in the burn out cycle. After casting the tree has to be cut as the pieces are connected to the middle stem, and this is often done in the casting section itself.

After cutting the pieces are sent to the filing department for hand or machine filing. The filing department is constituted of all male workers. The jewellery pieces are here put in a barrel which contains water and cutting chips of plastic or ceramic. The automated rotating movements of the barrel smooth the surface of the jewellery pieces as they come in contact with the chips. The production manager decides the exact composition of the chips and water, and the cycle, and workers operate the barrel. Again direct supervision by the management ensures higher productivity and tight labour control.

Once the pieces are taken out of the barrel they go to the polishing department. Polishing involves two sub processes, buffing and vibrating. In buffing there are two types of buffs, 'baal buff meaning hair buff and 'kapra buff' meaning cloth buff. The 'baal buff has a 
hairy surface, which provides the cutting action plus the removal of any holes that are left in the jewellery. The cloth buff helps to give a shine to the surface. These buffs are attached to a rotating motor and the worker holds the piece against the motor. The next step is polishing with the vibrator, the surface of which has small pins to dig into the jewellery and give it a further shine.

The jewellery pieces are next sent for plating in another department where they are hung on wires, which are then dipped into Ariel gas shampoo in an ultrasonic machine for one or two minutes. The pieces are then manually transferred to a vibrator, which cleans them for a specific time. Next the jewellery pieces are dipped in a tank of plating solution, the main component of which is sulphuric acid, which is pre-set for time and voltage. Polishing and plating are done by male workers and labour control is practised by supervision exercised by supervisors and managers, who are all men in this case.

After plating the jewellery is sent for packing. The packaging department in most companies is organised in a separate section of a hall. Before the actual packaging, the jewellery items are stamped with the company stamp and then categorised according to size and weight. Similar items, equivalent in size and weight, are then put in plastic bags, ten in each. Women are in the majority in the packaging department. The workers here have to keep a record of the pieces packed.

In the case of studded jewellery, stone setting is done after casting in gold or silver, predominantly by male workers. Some companies pay their workers on a piece rate basis whereas other companies pay a fixed wage. In case of fixed wage workers, record keeping and supervision are used for labour control. In Pratap Diamond Jewellers diamonds are set on to the wax piece itself. This process involves fixing the precious stone with glue on to the wax piece in a small channel. The worker has to match the stone size exactly with the channel made, using an eyeglass. Women workers are in preponderance here. The piece is then kept in the setting machine and the heat sets the diamond. After the diamond or precious stone is fixed in the wax mould, the piece is sent for gold casting, and the diamond gets fixed to the gold in the process of casting.

In most of the companies quality control occurs at every stage of the production process after casting. In all the stages of quality control the worker has to check the piece meticulously and has to pay attention to the size of the piece, its completeness, and must check for defects like porosity or any hole in the piece. In later stages the piece has to be checked for the uniformity of the polish, size and symmetry of the stone and the finish. There is an exclusive presence of women in quality control. However, the potential of women seeing themselves or being seen as decision makers here is reduced by constructing the job as routine work, good for workers with an eye for detail. This perception of quality control was conveyed to me by Ajay, the production manager of Raghav Jewellers: 'Women have an eye for detail and that is why we place them in quality control where they inspect the jewellery pieces closely. If you think about it, this is a routine job and quite repetitive'. Quality control was a separate section in the shopfloor so that women could not trace the cause of defective piece(s) to any particular person or exercise any authority through their role in accepting or rejecting the pieces. 
Thus, labour control regimes were facilitated through a gender division of labour both across different processes of production and through a hierarchy of male supervisors and managers.

\section{Company Profiles}

Table 1: A profile of the sample companies in machinemade jewellery production in NEPZ

\begin{tabular}{|c|c|c|c|c|c|c|}
\hline $\begin{array}{l}\text { Name of } \\
\text { the } \\
\text { Company }\end{array}$ & $\begin{array}{l}\text { Date of } \\
\text { Incorporation in } \\
\text { the Zone }\end{array}$ & $\begin{array}{l}\text { Type of } \\
\text { Machinemade } \\
\text { Jewellery } \\
\text { Produced }\end{array}$ & $\begin{array}{l}\text { Ownership } \\
\text { Type }\end{array}$ & \multicolumn{2}{|c|}{$\begin{array}{l}\text { Total Production } \\
\text { Workers in } \\
\text { Machinemade } \\
\text { Jewellery } \\
\text { Production, } \\
\text { June } 1996 \\
\text { Men Women }\end{array}$} & $\begin{array}{l}\text { Women as } \\
\text { percentage of } \\
\text { the Total } \\
\text { Production } \\
\text { Workers in } \\
\text { Machinemade } \\
\text { Jewellery }\end{array}$ \\
\hline $\begin{array}{l}\text { Raghav } \\
\text { Jewellers } \\
\text { Ltd }\end{array}$ & 1992 & $\begin{array}{l}\text { Studded gold and } \\
\text { silver jewellery }\end{array}$ & $\begin{array}{l}\text { Private Ltd } \\
\text { Resident } \\
\text { Indian Owned }\end{array}$ & $\begin{array}{l}30 \\
(1)\end{array}$ & $\begin{array}{l}5 \\
(5)\end{array}$ & 14.3 \\
\hline $\begin{array}{l}\text { Dimple } \\
\text { Jewellers } \\
\text { Ltd }\end{array}$ & 1991 & $\begin{array}{l}\text { Gold and silver } \\
\text { plain jewellery } \\
\text { and chains }\end{array}$ & $\begin{array}{l}\text { Public Ltd } \\
\text { Resident } \\
\text { Indian Owned }\end{array}$ & $\begin{array}{l}65 \\
(2)\end{array}$ & $\begin{array}{l}15 \\
(6)\end{array}$ & 18.75 \\
\hline $\begin{array}{l}\text { Victor } \\
\text { Jewellers } \\
\text { Ltd }\end{array}$ & 1989 & $\begin{array}{l}\text { Studded gold } \\
\text { jewellery }\end{array}$ & $\begin{array}{l}\text { Public Ltd } \\
40 \% \text { foreign } \\
\text { ownership }\end{array}$ & $\begin{array}{l}60 \\
(2)\end{array}$ & $\begin{array}{l}25 \\
(3)\end{array}$ & 29.4 \\
\hline $\begin{array}{l}\text { Chandra } \\
\text { Jewellers } \\
\text { Ltd. }\end{array}$ & 1993 & $\begin{array}{l}\text { Plain and } \\
\text { studded gold } \\
\text { jewellery, cut } \\
\text { and polished } \\
\text { diamonds } \\
\end{array}$ & $\begin{array}{l}\text { Public Ltd } \\
\text { Resident } \\
\text { Indian Owned }\end{array}$ & $\begin{array}{l}78 \\
(2)\end{array}$ & $\begin{array}{l}10 \\
(3)\end{array}$ & 11.4 \\
\hline $\begin{array}{l}\text { Bharat } \\
\text { Ratna } \\
\text { Jewellers } \\
\text { Ltd } \\
\end{array}$ & 1992 & $\begin{array}{l}\text { Plain and } \\
\text { studded gold and } \\
\text { silver jewellery }\end{array}$ & $\begin{array}{l}\text { Public Ltd } \\
35 \% \text { foreign } \\
\text { ownership }\end{array}$ & $\begin{array}{l}90 \\
(2)\end{array}$ & $\begin{array}{l}34 \\
(5)\end{array}$ & 27.4 \\
\hline $\begin{array}{l}\text { Pratap } \\
\text { Diamond } \\
\text { Jewellers } \\
\text { Ltd. } \\
\end{array}$ & 1987 & $\begin{array}{l}\text { Diamond } \\
\text { studded gold } \\
\text { jewellery }\end{array}$ & $\begin{array}{l}\text { Private Ltd } \\
\text { Resident } \\
\text { Indian Owned }\end{array}$ & $\begin{array}{l}102 \\
(1)\end{array}$ & $\begin{array}{l}53 \\
(5)\end{array}$ & 34.2 \\
\hline Total & & & & $\begin{array}{l}425 \\
(10) \\
\end{array}$ & $\begin{array}{l}142 \\
(27)\end{array}$ & 25.0 \\
\hline
\end{tabular}

Note: Figures in the brackets indicate the number of women and men workers interviewed.

Source: Compiled from the central NEPZ data, the company questionnaires and interviews with men and women workers, May 1996-January 1997. 
Table 1 details the year of incorporation, ownership type and gender composition of the labour force in different companies. Of the six companies only two, Victor Jewellers and Bharat Ratna Jewellers, have part foreign ownership. All the other companies are resident Indian owned. The proportion of women employed across the six companies varies from 11.4 percent in Chandra Jewellers to 34.2 percent in Pratap Diamond Jewellers. The proportion of women in Pratap Diamond Jewellers is particularly high because of a large number of women employed in wax stone studding. The proportions also differ with the extent of automation of the wax injection machines. The more automated the machine the lower is the proportion of women employed.

\section{DEMOGRAPHIC PROFILE}

Table A1 in the Appendix shows the demographic profiles, types of work, methods of selection, training, salaries and other benefits of thirty-seven workers, twenty-seven women and ten men, who constitute the respondents in my study of machinemade jewellery production in NEPZ.

As Table A1 shows, the age of women respondents varies between eighteen and thirty. The average age of a women respondent is approximately twenty-three years. The age of the men respondents vary between twenty and thirty-five, with the average being approximately twentysix years. The education of the women respondents varies between years two to masters' level across the sample, with the average around year ten. There is a large variation in the education level of the women respondents across different companies, it being particularly high in Bharat Ratna Jewellers. The education of the men respondents varies between years four to graduation, with the average at year eleven. The variation in education level of men respondents across the different companies is not as striking as it is for the women respondents.

Of the twenty-seven women respondents interviewed, sixteen are married, ten unmarried and one separated. This finding is in line with the studies on maquiladoras in Mexico (Tiano 1994; Fussell 2000) and in Indonesia (Caraway 2005) that note a prevalence of married women. The pattern of mainly unmarried women in export processing zones, noted in the earlier literature (Frobel, Heinrichs and Kreye 1980; Elson and Pearson 1981; Pearson 1991; Wolf 1992), may not be upheld in the case of machinemade jewellery in NEPZ. ${ }^{2}$ Nor does there appear to be a 'natural' turnover of women after marriage or childbirth. Ten of the women respondents have children and seven have at least one child less than or equal to five years of age. Of the seven respondents with a child of five or under, three had worked in the company since before the child was born.

Of the thirty-seven respondents, twenty-eight are first generation migrants from other states or from other districts of Uttar Pradesh. In Table A1, migration has been noted only if the worker herself/himself has migrated. The workers are from a range of different states - Uttar Pradesh, Bihar, Punjab, Madhya Pradesh, Himachal Pradesh, and West Bengal, and in some cases from a different country - Nepal. This shows the importance of migrant labour in the industry. Munoz (2008) in her study of the Tortilla factories in the US and Mexico observes the role of US immigration policy in creation of vulnerable workers on both side of the border. It 
creates a labour supply of a vulnerable group of undocumented Mexican men in the US and of vulnerable women who are single mothers in Mexico which is central to the regime of labour control on both sides of the border. In my case study the movement of workers within different regions in India is not controlled by the State. However, the preponderance of first generation migrant labour in the zone does facilitate labour control within the industry as these workers in most cases have little to fall back on.

Eighteen respondents were recruited formally and nineteen informally. ${ }^{3}$ In Dimple and Raghav Jewellers all recruitment is made informally, while in Bharat Ratna Jewellers all recruitment is made formally. In the other three companies a combination of formal and informal methods is used. Pearson (1998 150-51) discusses the male bias in the selection procedures of the ideal electronic worker in the maquiladoras, a combination of objective criteria of coordination and dexterity, social prejudice against mothers, class prejudice in demanding better education, and the sexist patriarchal fantasy of managers in selecting good looking women. In my case study the recruitment policies of the management differed across the companies in that the preference for higher educated women was prevalent in Chandra Jewellers and Bharat Ratan Jewellers but was not expressed by managers of other companies. According to the manager of Bharat Ratna Jewellers, 'We prefer to recruit better educated women as they seem to have better focus. However, we do not always get the ideal workers because of the remote location of NEPZ'. None of the managers expressed any overt bias in hiring better looking women or against mothers though all expressed dexterity as important in hiring and retaining women. Moreover in several cases the jobs were specified as suitable for men or women in the job advertisement itself. This is similar to the practice of gendered recruitment noted by Caraway (2005) in Indonesia.

\section{WAGE LEVELS, WORKING CONDITIONS AND LABOUR HIERARCHY}

The wage level of the women respondents varies between Indian Rupees (INR) $1100^{4}$ per month in Dimple Jewellers and INR 6000 per month in Bharat Ratna Jewellers. The overall average wage of the women respondents is approximately INR 2343 per month. However, large intercompany variations in the wage levels mean that the overall average is significantly affected by the number of women interviewed in each company. The wage level of the men workers varies between INR 1400 in Victor Jewellers and INR 4700 per month in Bharat Ratna Jewellers. The overall average wage level of the men respondents is approximately INR 2771 per month.

Discrimination against women is not so apparent in the wage level itself as in differences in the status of men and women. Perceptions of skill, transferability of some skills to the handmade jewellery sector and a policy of keeping women as 'permanently casual' in some companies advantaged men as a group over women as a group.

I next take up the categorization of men and women workers by skill in different companies ${ }^{5}$, based on the company survey results. As we can see from Table 2, of the total men workers, 33.6 percents are categorized as skilled workers by the management. On the other hand, of the total women workers, negligible levels of .01 percent are categorized as skilled, all in the 
same company, Chandra Jewellers. There are large variations in the number of men categorized as skilled workers across the companies, from 17.8 percent to 100 percent. Of the total men workers, 45.6 percent are in the semi-skilled and 20.7 percent in the unskilled category. Of the total women workers, 65.5 percent are in the semi-skilled and 33.1 percent in the unskilled category.

Table 2: Categorization of workers in machinemade jewellery production by skill

\begin{tabular}{|c|c|c|c|c|c|c|c|c|}
\hline $\begin{array}{l}\text { Name of } \\
\text { the } \\
\text { Company }\end{array}$ & \multicolumn{2}{|c|}{$\begin{array}{l}\text { Skilled } \\
\text { Men Women }\end{array}$} & \multicolumn{2}{|c|}{$\begin{array}{l}\text { Semi Skilled } \\
\text { Men Women }\end{array}$} & \multicolumn{2}{|c|}{$\begin{array}{l}\text { Unskilled } \\
\text { Men Women }\end{array}$} & \multicolumn{2}{|c|}{$\begin{array}{l}\text { Total } \\
\text { Men Women }\end{array}$} \\
\hline $\begin{array}{l}\text { Raghav } \\
\text { Jewellers }\end{array}$ & $\begin{array}{l}30 \\
(100 \%)\end{array}$ & 0 & 0 & $\begin{array}{l}5 \\
(100 \%)\end{array}$ & 0 & 0 & $\begin{array}{l}30 \\
(85.7 \%)\end{array}$ & $\begin{array}{l}5 \\
(14.3 \%)\end{array}$ \\
\hline $\begin{array}{l}\text { Dimple } \\
\text { Jewellers } \\
\text { Ltd }\end{array}$ & $\begin{array}{l}20 \\
(30.8 \%)\end{array}$ & 0 & $\begin{array}{l}30 \\
(46.15 \%)\end{array}$ & $\begin{array}{l}10 \\
(66.7 \%)\end{array}$ & $\begin{array}{l}15 \\
(23.1 \%)\end{array}$ & $\begin{array}{l}5 \\
(33.3 \%)\end{array}$ & $\begin{array}{l}65 \\
(81.25 \%)\end{array}$ & $\begin{array}{l}15 \\
(18.75 \%)\end{array}$ \\
\hline $\begin{array}{l}\text { Victor } \\
\text { Jewellers } \\
\text { Ltd }\end{array}$ & $\begin{array}{l}17 \\
(28.3 \%)\end{array}$ & 0 & $\begin{array}{l}27 \\
(45 \%)\end{array}$ & $\begin{array}{l}10 \\
(40 \%)\end{array}$ & $\begin{array}{l}16 \\
(26.7 \%)\end{array}$ & $\begin{array}{l}15 \\
(60 \%)\end{array}$ & $\begin{array}{l}60 \\
(\mathbf{7 0 . 6} \%)\end{array}$ & $\begin{array}{l}25 \\
(29.4 \%)\end{array}$ \\
\hline $\begin{array}{l}\text { Chandra } \\
\text { Jewellers } \\
\text { Ltd. }\end{array}$ & $\begin{array}{l}20 \\
(25.6 \%)\end{array}$ & $\begin{array}{l}2 \\
(20 \%)\end{array}$ & $\begin{array}{l}16 \\
(20.5 \%)\end{array}$ & 0 & $\begin{array}{l}42 \\
(53.8 \%)\end{array}$ & $\begin{array}{l}8 \\
80 \%)\end{array}$ & $\begin{array}{l}78 \\
(88.6 \%)\end{array}$ & $\begin{array}{l}10 \\
(11.4 \%)\end{array}$ \\
\hline $\begin{array}{l}\text { Bharat } \\
\text { Ratna } \\
\text { Jewellers } \\
\text { Ltd }\end{array}$ & $\begin{array}{l}16 \\
(17.8 \%)\end{array}$ & 0 & $\begin{array}{l}74 \\
(82.2 \%)\end{array}$ & $\begin{array}{l}34 \\
(100 \%)\end{array}$ & 0 & 0 & $\begin{array}{l}90 \\
(72.6 \%)\end{array}$ & $\begin{array}{l}34 \\
(27.4 \%)\end{array}$ \\
\hline $\begin{array}{l}\text { Pratap } \\
\text { Diamond } \\
\text { Jewellers } \\
\text { Ltd. }\end{array}$ & $\begin{array}{l}40 \\
(39.2 \%)\end{array}$ & 0 & $\begin{array}{l}47 \\
(46.1 \%)\end{array}$ & $\begin{array}{l}34 \\
(64.15)\end{array}$ & $\begin{array}{l}15 \\
(14.7 \%)\end{array}$ & $\begin{array}{l}19 \\
(35.85)\end{array}$ & $\begin{array}{l}102 \\
(\mathbf{6 5 . 8 \%})\end{array}$ & $\begin{array}{l}53 \\
(34.20 \%)\end{array}$ \\
\hline Total & $\begin{array}{l}143 \\
(33.6 \%) \\
(\mathbf{9 8 . 6 \% )}\end{array}$ & $\begin{array}{l}2 \\
(.01 \%) \\
(\mathbf{1 . 4 \% )}\end{array}$ & $\begin{array}{l}194 \\
(45.6 \%) \\
(67.6 \%)\end{array}$ & $\begin{array}{l}93 \\
(65.5 \%) \\
(\mathbf{3 2 . 4 \% )} \\
\end{array}$ & $\begin{array}{l}88 \\
(20.7 \%) \\
(\mathbf{6 5 . 2 \%} \%\end{array}$ & $\begin{array}{l}47 \\
(33.1 \%) \\
(34.8 \%)\end{array}$ & $\begin{array}{l}425 \\
(\mathbf{7 4 . 9 6 \% )} \\
\end{array}$ & $\begin{array}{l}142 \\
(\mathbf{2 5 . 0 4 \% )}\end{array}$ \\
\hline $\begin{array}{l}\text { Total (both } \\
\text { sexes) }\end{array}$ & & 45 & & 87 & & & 56 & \\
\hline
\end{tabular}

Note: The figures in plain brackets are the percentage of skilled, semi skilled or unskilled women or men workers to all women or men workers in each company. The figures in bold brackets are the percentage of women or men workforce to total women and men workforce in each category respectively.

Source: Based on the company questionnaires, May 1996-January 1997

Men workers are 75 percent of total workers so they are over represented at 98.6 percent of the skilled workers and underrepresented at 67.6 percent of the semi-skilled and 65.2 percent 
of the unskilled workers. On the other hand, there is a vast under representation of women at 1.4 percent of the skilled workforce in relation to their overall representation of 25 percent. Women are over represented in the semi-skilled and skilled categories, at 32.4 percent and 34.8 percent respectively.

I next take up an analysis of the discourses which constitute and are in turn constituted by a labour hierarchy and a gender division of labour, and their relatedness to the gendered subjective identities of men and women.

\section{Gendering of Machinemade Jewellery Production in NEPZ: Discourses, Practices and Subjectivities}

In machinemade jewellery production the tasks were constructed as suitable for women or men according to essential biological differences. In most cases neither had much 'choice' over their section of work and all decision regarding placement were made by the management However, by investing in the discourses on masculinized and feminized jobs, men and women constructed their masculine and feminine subjectivities. The regime of labour control had mixed elements of despotism and hegemony here.

\section{DISCOURSE OF POLISHING, STONE STUDDING AND FILING AS 'TOUGH'}

The most important discourses provided by the entrepreneurs and managers for the inclusion of men and exclusion of women in the casting, polishing, stone studding and filing sections rely on gender essentialism. These jobs are constructed as tough and therefore suitable for men, who are essentialized as strong and unsuitable for women, essentialized as weak. According to the manager of Bharat Ratna Jewellers 'Filing, buffing and plating are male dominated operations as filing and buffing are considered heavy and plating involves use of chemicals'. According to the manager of Dimple Jewellers 'Women are absent from polishing because force is required while buffing and grinding. One has to push the piece against the wheel. So the strain is felt by the shoulders and it is quite physically oriented'. As to the absence of women from casting he said 'Casting is done at very high temperatures. For example the furnace is at 700 degrees centigrade and molten metal is at 1000 degrees centigrade. So we prefer men here'.

Men workers also relied on the binaries of tough/light to constitute their work in the former category and that of the women in the latter. Here the binary polarizes the categories where the former category 'tough' serves as the 'master signifier' and the latter category 'light' is impelled to a subordinate position. These resemble the gendered polarities of work elaborated in the study by Game and Pringle (1983). According to Hari, doing polishing in Bharat Ratna, 'Polishing is dangerous and tough work. I used to even burn my hands with the friction produced by the barrel earlier. It is not a woman's job'. Master moulds are made primarily by men who have had experience of working in handmade jewellery production. Thus the discourses and practices which exclude women from handmade jewellery production ${ }^{6}$ are also pertinent to their exclusion from master mould making in machinemade jewellery production. 
Lalit, a master maker, when speaking of the absence of women from master making said 'Soldering, wiring, drawing a wire, all this requires power. Beating the metal with a hammer, melting the metal is tough. Not everyone can do it.' Here Lalit uses the term 'not everyone' to refer to women, constructing them as different and the 'other'.

The material element of this exclusion is clear in the statement of Pradeep Nayak, a mastermaker in Pratap Diamond Jewellers:

Women might be able to make a master, but if we allow women entry into handmade jewellery production and thereby in master making, our wage levels and conditions of work will go down, for women will be ready to work at low wages and accept worse conditions of work, like working free for overtime. This will also render some of the men artisans unemployed.

Here in the narrative of women's acceptance of low wages and worse conditions of work one can see the gendered construction of women as 'cheap' and 'docile' constituting their identities as secondary workers. However, there were several instances of women's resistance which represent disruptions to their constitution as secondary workers. This also clearly demonstrates the fragility of the boundaries of the GDL which need to be guarded by male workers as well to maintain the fiction of men as skilled and women as unskilled workers.

Some women workers invested in the discourses that master making, casting, polishing and studding are tough and as such men's work. For example Purnima went on to describe the difficult aspects of the work - 'In the case of finishing the machine gets very hot when operating it and can cause friction in the nails and hands'. However, there were others like Alka who in her acceptance of the gendered division of labour shows a nuanced combination of accommodation and subversion as indicated by Ram (1991: 234) in her ethnographic study of Mukkuvar women in Kanyakumari, India. According to Alka 'I have noticed that women are always predominantly in the wax department, though we can learn and do the work in casting, filing or any other department. Women can learn and do the same work as men but we have little choice in deciding the department we would like to work in'. This underlines the limited 'choice' of workers and the hierarchical masculinist structures of the companies where the managers used their power to create and reinforce a GDL which enabled a gendered regime of labour control.

A brief consideration of women's reproductive work in India readily undermines their apparent unsuitability for the work. When so many women in India are involved in drawing water from wells and carrying it over long distances, why should the semi automated process of polishing be particularly heavy? Moreover, a large part of women's time is spent near the hot stove and open flames in the kitchen, so why should working near a hot furnace be particularly tough?

Here the narrative of the tasks as 'dangerous', 'tough', 'difficult' and physically oriented helps to constitute the masculine subjectivities of the men who perform these tasks as 'brave', 'tough', 'strong' and 'muscular'. These are built in opposition to the feminine subjectivities of women as 'timid', 'tender', 'weak' and 'delicate'. 


\section{DISCOURSE OF WAX CASTING, PACKING AND QUALITY CONTROL AS 'LIGHT WORK'}

Working in parallel to the discourses justifying women's exclusion from master making, stone studding and filing were those justifying their inclusion in wax casting, packing and quality control. According to the director of Raghav Jewellers, 'Women are suited to distribution and quality control as they are more cautious with the pieces and have an eye for detail'. However, the 'caution' and 'eye for detail' exercised by women in quality control did not translate into their categorization as 'skilled workers'. As to the preponderance of women in the wax department, particularly in injection, cleaning and tree formation, the popular discourse among the managers and entrepreneurs was that it is 'light' work and is thus suitable for women. Packaging was constructed as 'routine' and 'easy' work. The managers again focused on essentializing the physical and the mental attributes of women. According to the production manager of Dimple Jewellers, 'Women are suitable for wax cleaning as they have delicate hands and can do delicate work'.

The 'delicate hands' and the 'eye for detail' which women acquire through performing tasks like sewing and cleaning grains is essentialized as the natural trait of femininity and helps to constitute feminized jobs. This is similar to the construction of assembly jobs as suitable for women in the electronic factories of the multinationals in SE Asia and Latin America in the 1960s and the '70s because of their 'natural' dexterity (Elson and Pearson 1981).

Though some women reinforced some essentialized ideas around wax work as women's work, they used this construction to their advantage, displaying their agency. Most took pride in their work, stressed its importance in the process and thought that men would not be able to do it as well. As Purnima explains: 'Wax is soft and is to be handled softly. Women have the skill to do it. Men have got hard hands and if they are impatient they can spoil the wax moulds - they might open it too quickly. This can spoil the pieces.' Here women redeploy the discourse of wax work as women's work to their advantage by valorizing it as requiring 'ability' and 'skill' and in constructing men as unfit to perform it. They debunk their construction as unskilled workers by underlining the special skills needed to handle wax. This resembles what Butler (1995: 131) would term as the '...appropriation of a narrative for a political purpose for which it was explicitly not devised' or what Ped (1990: 46-47) would call 'to seize language for their own purposes'.

Amita on the other hand seemed to be accepting of the non transferability of women in the gold department. According to her, 'Yes women are mostly found in the wax department. Actually gold and silver are hard for women to handle.' According to Purnima, 'Quality control is good work, light and clean, as it should be for a woman. But women are not asked the choice when allocating a department, so that we have to go in whichever department the management decides to post us.'

Thus we find that different actors give different meanings to the gender division of labour in different contexts. Investing in the discourses on the gender division of labour allowed some women to take pride in their femininity through an emphasis on keeping their hands soft, not damaging their nails and recognizing their delicacy of touch. Others valorized their work 
thus posing a challenge to its construction as 'unskilled'. Moreover, many women saw their paid work as time away from their children and home which needed to be compensated better. Several of them saw their work as important to fend for their families and for better education for their children, and expressed a contradiction in their interpellation as 'unskilled' and 'secondary workers' with their responsibilities in household budgeting. Janaki expressed this very succinctly:

I had talked to the Manager and told him everything: we work so hard here, we are away from our families and children for long hours, we need some recognition and better compensation. You seem to think that our work is easy - but it is not. Everything is so expensive now a days - you should raise our wages and make us permanent. I told him how the daily necessities like flour and oil have become so expensive. He said I do not purchase these things so how do I know the price of them. I told him you do not purchase them but I do.

Here we see Janaki's valorization and recognition of her role as a worker and home-maker in demanding a better wage from the management.

One could question whether quality control work done by women posed a challenge to men's masculinity? By making decisions about the quality of the piece, women could indicate the piece as faulty, which meant that the piece had to be taken back to the relevant department and either corrected or redone. However, the quality control was a separate section and women did not directly interact with the men in different sections. Thus, the men did not face a challenge to their masculinity or self worth through the direct control of their output by the women in the quality control department. I would argue that the subversive potential of women engaged in quality control is reduced through the practices of compartmentalization of quality control such that women engaged in quality control do not present a direct disruption to the masculinized hierarchical order where men are constructed as more skilled than women, thus preserving the fiction of male supremacy.

\section{CROSSING THE BOUNDARIES OF THE GENDER DIVISION OF LABOUR?}

All the above makes the few cases when the boundaries of the gender division of labour had been crossed especially interesting. How in the face of the disruptions to the gender divisions of labour were the coherence of the gendered categories maintained? How did these disruptions present breaks to the gendered discourses?

In Dimple Jewellers two men were working in mould cutting in the wax department which was otherwise feminized. Here mould cutting was constructed by the manager as 'the toughest job in the wax department, involving cutting the mould with a sharp knife', thus preserving the masculinity of the men doing this work. The construction of mould cutting as tough also helped the management to justify higher wage level for mould cutting within the wax department. Several researchers (Morgan 1992; Collinson and Hearn 1994; Connell 1995, 1993; Kerfoot and Knights 1998) have underlined the importance of work as central to 
masculine identity and the role of organizations in construction of masculinity. The men also described their work as 'tough', and as 'different from other jobs in the wax department' to reaffirm their masculine identities when working in an otherwise feminised section of jewellery production. This resembles the argument made by McDowell and Court (1994) as to how men and women realign the gendered meanings of jobs to their own sense of self.

In Pratap Diamond Jewellers, stone studding was carried out on wax cast pieces and only women were recruited to this work. The preponderance of women in wax stone studding, in contrast to their total absence from metal stone studding, was justified by the managers on the ground that '... wax stone studding involved pushing an exact sized diamond in a small channel, work which required an eye for detail and a lot of concentration for which women were suitable.' The women were taken on as a rotating pool of workers, many of them having their employment terminated before the completion of three months of probation.

A significant example of boundary crossing is found in Chandra Jewellers, where both men and women had been recruited as trainees in the metal studding section. However, on completion of training all the four women involved were transferred to the wax casting department, as Naveen, the production manager of Chandra Jewellers, explains:

Setting can be of different kinds - grain setting, prong setting and metal setting, of which women were given relatively easy setting operations mainly to do with metal setting. However, women were slow to learn and training women for setting took seven months in contrast to four months for men workers. Later we thought that women are not really fit for this job and transferred them to the wax casting department.

Thus, although the company recruited both men and women as trainees in the stone studding section, the management had an inherent gender bias as to their capacities and women were trained only in metal setting, which the management considered easy. Subsequently the management reinstated the gender division of labour by transferring women to the wax casting department. The grounds cited are that women took longer to learn the work, but why then did the management decide to transfer the women only after the training was over? By transferring women to the wax casting department the management attempted to foreclose the challenges to masculinity which could have been posed by women performing 'tough' male work. Thus, we find that gendered discourses were used by the management to reproduce the gender division of labour and to produce masculine men and feminine women. The evoking of gendered subjectivities was an important way in which labour was controlled, for as Salzinger (2003: 28) has argued, labour control depends on manager's capacity to address workers in terms they recognise and accept. However, these discourses were not hegemonic and the discourse of women as inherently incapable of doing 'tough' male work was questioned by several women.

\section{DISCOURSE CONTESTATION}

One of the four workers, Malini, protested against her transfer, but management did not reverse its decision. According to Malini: 
Women are no less than men in any work. When we were trained in setting, why were we sent to the wax casting department? When we came here initially we were told that women can do any work and that metal setting is hard, but that we could do it. However, I did not find it particularly hard. So I resented being transferred to the wax casting department. Although the initial wage levels in the wax casting department were the same as in stone studding, the future promotions in the former were much less. Thus I cannot think of a long term career in jewellery production remaining in the wax department.

Malini here questioned the gendered division of labour and the essentialization of stone studding as man's work. She resented her transfer to wax department and showed her non acceptance of her subjective construction as 'unskilled' and 'delicate'. In displaying her concern about her future career in wax department she presented a subversive rupture to the discourse of women as 'secondary workers'. However, despite her resentment with her work, Malini continued to work for Chandra Jewellers for she could not find another job and needed to support herself and her parents. This vulnerability was common for several workers, with very few jobs available.

\section{DISCOURSES ON SKILL AND TRAINING}

The gender division of labour is tied to a discourse that many jobs defined as men's jobs are skilled and almost all jobs defined as women are semi-skilled or unskilled. The discourse of men's jobs as more skilled than women's jobs meant a greater proportion of men represented as skilled workers than women, as has been outlined in the earlier section. Deepa Sharma, a woman and the export manager of Victor Jewellers, also invested in this popular discourse:

Masterpiece making, setting and designing are all considered skilled work. However, in case of setting, quantity and quality were considered before categorizing a person as a skilled worker. The unskilled category workers were involved in filing, wax and packaging sections. Women were not found as skilled workers because they were not available.

This statement demonstrates the male bias inherent in the concept of skill which is tied to a power hierarchy, whereby men's jobs are considered more skilled and better valued than women's jobs.

According to the director of Dimple Jewellers, Manoj, "Women workers are less productive than men, as "skilled" workers and supervisors because they lack concentration and are mentally preoccupied with their household responsibilities. However, they are more productive than men as "semi-skilled" or "unskilled workers". This statement again reveals a great deal about the male bias in decisions about what constitutes 'skill'. If women lack concentration to do the 'skilled' jobs, how do they get the concentration to do the 'delicate', 'detailed', 'dexterous' jobs which are classified as unskilled? This leads us to the argument that 
women's job are constructed as 'unskilled' because they are done by women, who are secondary workers and are not socially recognized as 'breadwinners' (Elson and Pearson 1981; Phillips and Taylor 1980). Furthermore, what is interesting to note here is that to ensure the higher productivity of women as 'unskilled' and 'semi-skilled' workers they were made to sign on target sheets in the wax department of Dimple jewellers.

Skill categorization is often tied to requirements for training. I found in the course of my research that training is a fluid concept, interpreted differently by different people and varying in its usage. However, the discourse of tasks done by men workers as skilled and requiring training is popular among managers and constituted the dominant discourse. For the owner of Raghav Jewellers, Karan, 'Casting is not a woman's job because it requires the person to be strong, healthy and also requires real training'. It is important to note that while Karan rejected the need for any 'real training' for women in the wax department he also admitted that he tried to prolong the 'trainee' status of women in order to prolong their casual status which allowed him to pay women lower wages with no benefits for a prolonged period. According to Shrinivas, the manager of Pratap Diamond Jewellers, 'Women are assigned to easy tasks, which take a day or two to learn, for they do not have to think of wage work as a career. But for men on the shopfloor, training could be a life time investment.' From the above statement one can read the essentialization of women as secondary workers whose prime identities are tied to their domestic role and who are thus assumed to not give primacy to their careers.

The common assumption in the dominant discourse of the managers is that women do jobs which do not require training. Another way of looking at this is that women bring skills to the job that they have already acquired. Elson and Pearson (1981: 93) note that the 'nimble fingers' of women workers in electronic and textile factories are not natural but the result of training received from their mothers and other women kin in tasks which are deemed socially appropriate like sewing. A similar argument could be applied to the 'nimble' and 'delicate' fingers women bring to wax casting. Similarly the much-desired 'eye for detail' required for quality control is not a natural trait of women but the result of informal training in household tasks like cleaning grains, needle work, and knitting.

The perception of women as to what constituted their training period varied across the respondents. According to Alka, working in the wax department of Dimple Jewellers, 'I started working in the department after observing other women do it for a day or two. I think that constitutes my training period.' On the other hand, for women like Purnima, training constituted the entire six months when she perfected the cleaning of wax pieces. Men workers perceived their training to be longer than that of women workers. Lalit, who had moved from handmade jewellery production to master making, said 'I have been doing hand jewellery work for the last twenty years, so it took me a few days to make a master, but for men who are trained in master making in the company, training would take more than a year.' Manav of Dimple Jewellers felt that he was continuing to be trained after nearly three years of working in the plating section.

The dominant discourse that men need training and women require little training was tied to the practice of sending men on training courses in organizations such as the Gems and Jewellery Promotion Council, and of categorizing their work as skilled in relation to that of 
women. Thus the meaning and effect of training differed for men and women. For men it served as a means of valuing their work and categorizing them in higher skill categories. For women it served to prolong their casual employment status and lower their wages.

\section{DISCOURSE CONTESTATIONS}

The continuation of the temporary status of many women employees by the management represents what Foucault (1982: 790) would call 'modes of action...which were destined to act upon the possibilities of action of other people'. By extending their trainee status the management not just saved on the benefits and wages but also reduced the possibility of resistance by women workers, due to the increased threat of job loss represented in their status a 'temporary' producing the women workers as 'docile'. However, there were several instances when women workers reworked the foreclosures to resistance and questioned this construction.

In one instance all the women working in Dimple Jewellers got together to protest against the non-issuing of a permanent gate pass. It is important to understand that this was the first issue around which all workers of a company had come together to protest. Janaki, one of the outspoken women workers explained:

Several times I have refused to sign the target sheets and have questioned our status as 'unskilled'. However, women working with me are never ready to come together to protest as they see the gendered skill categorization to be widespread. They are too afraid to lose their jobs. Only in one instance did we all come together to protest-this was on the issue of a permanent gate pass, for a temporary gate pass increased the insecurity of our jobs.

Thus, women protested their continued temporary status and not their skill categorization for the former increased the precariousness of their job and threatened their livelihood. As noted some women accepted the GDL while others questioned it. However, in no instance did all come together to protest gendered skill categorization as several believed it to be deeply entrenched, widespread and difficult to change. This is how Amita related the incident:

Once all of us decided that we will protest against the non-issue of permanent gate passes to all the women in the company by sitting outside the boundary of the zone. Then two women - Poonam and Sunyana went inside thinking that they will negotiate directly with the production manager, but they did not come back and in fact were made to join the work. We kept waiting for them outside until 1:30 p.m., and then we returned home. Though nothing concrete came out, we felt strong and united. We could show the management that we are not docile.

The company practices of prolonged temporary status of women feeds into the construction of women as 'cheap', 'unskilled' and 'docile'. Women, however, question these constructs through overt resistance and contestations. By valuing their work in the wax and 
quality control departments they resignify it. By questioning their status as 'unskilled', 'temporary' and 'cheap', women question their normalization as 'docile' and as 'secondary workers'. For as Butler (1993: 126-127) would put it '...the forcible approximation of a norm one never chooses, a norm that chooses us, but which we occupy, reverse, resignify to the extent that the norm fails to determine us completely'.

\section{Conclusions}

This paper has analyzed the role of discourse, practice and feminine and masculine subjectivities in gendering the labour market in machinemade jewellery production in NEPZ. The discourses on masculinized work of master making, gold casting, stone studding and polishing constitute these jobs as 'tough', 'heavy' and 'difficult', in contrast to feminized work of wax casting and quality control which are constituted as 'delicate', 'light' and 'easy'. These gender divisions of labour are tied to underlying material power dynamics where men's jobs are considered more skilled, are at higher wage levels, are more stable and have a career structure, where as women's jobs are considered unskilled, are at lower wage levels and are static. Performance of masculinized tasks constructs men's subjective identities as tough, strong and bold. Women, however have more nuanced subjectivities. Though some women at some points invest in their subjective identities as nimble fingered, delicate and soft, others do not accept the labour hierarchy and even overtly question the gender division of labour. Through subversive performance of their feminine work as valuable and through the questioning of the gender divisions of labour women challenge their construction as 'unskilled', 'docile' and 'secondary workers'.

The analysis of the above case study has underlined the importance of an eclectic framework where structural theories like Marxism are combined with postmodernism to understand how structural inequalities are reproduced through daily discursive and material practices, how women and men invest into discourses that feed into their subjective identities, and how the contestations of women creates space for alternative discourses and subjectivities. The study is useful in understanding the interrelationship of global and local as they impinge on the lived experiences of women and men.

\section{ACKNOWLEDGEMENTS}

An earlier version of this paper was presented in the Annual Conference of CASCA, Human Nature/Human Identity: Anthropological Revisionings, Concordia University Montréal, Québec, Canada May 9 to 14, 2006 and in the Annual Conference of CWSA/ACEF, 29-31 May 2006, York University, Toronto ON, Canada. I am grateful to the two anonymous referees for their comments and suggestions. My special thanks to Joanna Liddle, Caroline Wright, Suzanne Bergeron, and Tanya Basok, and Charlotte Yates for their continued support and advice. 


\section{NOTES}

${ }^{1}$ Some researchers (Berik 1996; Henry 2003; Schrijvers 1993) have noted their dilemmas of representation in the field. However, in their cases it was the marital status, dress, and/or a conformation to gender norms which were the issue.

2 The respondents were not selected systematically because the entrepreneurs and managers largely controlled access. Thus the sample is not random or representative. It is thus difficult to say that the pattern of marriage or singlehood is representative of the population. On the other hand the respondents represent a high proportion of the total women employees in the six machinemade jewellery units (19 percent), and so the proportion of married women is suggestive of a wider pattern.

${ }^{3}$ By formal method of recruitment I mean recruitment through advertisement of the post and a consequent interview. By informal method of recruitment I mean recruitment primarily through a contact in the company and with or without an interview.

${ }^{4}$ The average exchange rate of the rupee varied between INR 52.66 to INR 71.8 to the Pound Sterling and between INR 26.1 to INR 27.9 to the Canadian dollar from 1996-98.

${ }^{5}$ Interviews with the entrepreneurs/management showed that the skill categorisation by the management in many cases is not based on government legislation on skill; indeed many entrepreneurs/managers said that they were not aware of any such skill categorisation by the government. Instead the managers filled in the questionnaire according to their perception of skill, and in many cases tied this to the requirements of training.

${ }^{6}$ For a discussion of the discourses around the construction of handmade jewellery work as masculine refer to Soni-Sinha (2006).

\section{REFERENCES}

Andermahr, S., Lovell, T. and Wolkowitz, C. (1997) A Concise Glossary of Feminist Theory. London: Arnold.

Balakrishnan, R. and Sayeed, A. (2002) 'Subcontracting, the Push-Pull Factor' in R. Balakrishnan (ed) The Hidden Assembly Line: Gender Dynamics of Subcontracted Work in a Global Economy (pp. 237-298). Connecticut: Kumarian Press. 
Banerjee, N. (1983) Role of Women Workers in Export Oriented Industries, Five Case Studies of West Bengal. New Delhi: ICSSR.

Banerjee, N. (1991) 'The More It Changes the More It Is the Same - Women Workers in Export Oriented Industries', in N. Banerjee (ed) Indian Women in a Changing Industrial Scenario (pp. 237-298). New Delhi: Sage Publishers.

Berik, G. (1996) 'Understanding the Gender System in Rural Turkey: Fieldwork Dilemmas of Conformity and Intervention', in D.L. Wolf (ed) Feminist Dilemmas in Fieldwork (pp. 56-71). Oxford: Westview Press.

Braunstein, E. (2006) 'Foreign Direct Investment, Development and Gender Equity: A Review of Research and Policy', Occasional Paper 12. Geneva: United Nations Research Institute for Social Development.

Burawoy, M. (1985) The Politics of Production: Factory Regimes Under Capitalism and Socialism. London: Verso.

Butler, J. (1993) Bodies That Matter: On the Discursive Limits of Sex. London: Routledge.

Butler, J. (1995) 'For a Careful Reading', in S. Benhabib, J. Butler, D. Cornell and N. Fraser (eds) Feminist Contentions: A Philosophical Exchange (pp. 127-143). New York, London: Routledge.

Butler, J. (1996) 'Imitation and Gender Insubordination', in A. Garry and M. Pearsall (eds)Women, Knowledge, and Reality: Explorations in Feminist Philosophy (pp. 371-387). New York and London: Routledge.

Canning, K. (1994) 'Feminist History after the Linguistic Turn: Historicizing Discourse and Experience'. Signs: Journal of Women in Culture and Society 19(2): 368-404.

Caraway, T.L (2005) 'The Political Economy of Feminization: From "Cheap Labour" to Gendered Discourses of Work', Politics \& Gender 1(3): 399-429.

Chapkis, W. and Enloe, C. (eds) (1983) Of Common Cloth: Women in the Global Textile Industry. Amsterdam: Transnational Institute.

Cockburn, C. (1983) Brothers: Male Dominance and Technological Change. London: Pluto Press.

Collinson, D.L (1992). Managing the Shopfloor, Subjectivity, Masculinity and Workplace Culture. Berlin: Walter de Gruyter. 
Collinson, D.L. and Hearn, J. (1994) 'Naming Men as Men: Implications for Work, Organizations and Management', Gender, Work and Organization 1(1): 2-22.

Connell, R.W. (1995) Masculinities. Berkeley: University of California Press.

Cheng, C. (1996) Masculinities in Organizations. Sage Publications.

Elson, D. and Pearson, P. (1981). 'Nimble Fingers Make Cheap Workers: An Analysis of Women's Employment' in Third World Export Manufacturing', Feminist Review 7: 87-107.

Elson, D. (1983) 'Nimble Fingers and other Fables' in W. Chapkis and C. Enloe (eds) Of Common Cloth: Women in the Global Textile Industry (pp. 15-24). Amsterdam: Transnational Institute.

Ford, A. (1985) Men. London: Weidenfeld and Nicolson.

Foucault, M. (1979) The History of Sexuality, An Introduction. Volume 1. London: Allen Lane.

Foucault, M. (1982) 'The Subject and Power', Critical Enquiry 8(4): 777-789.

Frobel, F. Heinrichs, J. and Kreye, O. (1980) The New International Division of Labour: Structural Unemployment in Industrialized Countries and Industrialization in Developing Countries. Cambridge and London: Cambridge University Press.

Fuentes, A. and Ehrenreich, B. (1983) Women in the Global Factory. Boston: South End Press.

Fussell, E. (2000) 'Making Labor Flexible: The Recomposition of Tijuana's Maquiladora Female Labor Force', Feminist Economics 6(3): 59-79.

Game, A. and Pringle, R. (1983) Gender at Work. Sydney: Allen and Unwin.

Grossman, R. (1980) 'Women's Place in the Integrated Circuit'. Radical America 14(1): 29-49.

Henriques, J., Hollway, W., Urwin, C., Venn, C. and Walkerdine, V. (eds) (1984) Changing the Subject: Psychology, Social Regulation and Subjectivity. London and New York: Routledge.

Henry, M.G. (2003) “"Where Are You Really From?” Representation, Identity and Power in the Fieldwork Experience of a South Asian Diasporic', Qualitative Research 3(2): 229-242.

Hossfeld, Karen, J. (1990) “Their Logic Against Them”: Contradiction in Sex, Race, and Class in Silicon Valley', in K. Ward (ed) Women Workers and Global Restructuring (pp. 149-178). Ithaca: ILR Press. 
Ingham, M. (1984) Men: The Male Myth Exposed. London: Century Publishing.

International Labour Organization (2002) Employment and Social Policy in Respect of Export Processing Zones, GB.285/ESP/5.Geneva: ILO.

Joekes, S.P. (1987) Women in the World Economy: An INSTRAW Study. New York: Oxford University Press.

Joekes, S.P. (1995) 'Trade - Related Employment for Women in Industry and Services in Developing Countries', Occasional Paper 5. Geneva: United Nations Research Institute for Social Development.

Joekes, S.P. and Weston, A. (1994) Women and the New Trade Agenda. New York: United Nation Development Fund for Women.

Kalpagam, U. (1994) 'Labour in Small Industry: The Case of the Garment Export Industry in Madras City', in U. Kalpagam, Labour and Gender, Survival in Urban India (pp. 155-192). New Delhi: Sage Publications.

Kerfoot, D. and Knights, D. (1998) 'Managing Masculinity in Contemporary Organizational Life: A “Man”agerial Project', Organization 5(1): 7-26.

Kondo, D.K. (1990) Crafting Selves, Power, Gender and Discourse of Identity in a Japanese Workplace. Chicago and London: The University of Chicago Press.

Lal, J. (1996) 'Situating Locations: The Politics of Self, Identity and "Other" in Living and Writing the Text', In D.L. Wolf (ed) Feminist Dilemmas in Fieldwork (pp. 185-210). Boulder: Westview Press.

Lim L.Y.C. (1990) 'Women's Work in Export Factories: The Politics of a Cause' in I. Tinker (ed) Persistent Inequalities, Women and World Development (pp. 101-119). Oxford: Oxford University Press. 119-????

McDowell, L. and Court, G. (1994) 'Missing Subjects: Gender, Power and Sexuality in Merchant Banking', Economic Geography 70(3): 229-251.

McLaughlin, L. (1999) Beyond "Separate Spheres": Feminism and the Cultural Studies/ Political Economy Debate', Journal of Communication Inquiry 23 (4): 327-354. 
Mohanty Talpade, C. (1991) 'Under Western Eyes: Feminist Scholarship and Colonial Discourses', in C. Mohanty Talpade, A. Russo, and L. Torres. (eds) Third World Women and the Politics of Feminism (pp. 51-80). Indiana: Indiana University Press.

Mohanty Talpade, C. (2002) “'Under Western Eyes” Revisited: Feminist Solidarity Through Anticapitalist Struggles', Signs: Journal of Women in Culture and Society 28(2): 499-535.

Morgan, D.H.J. (1992) Discovering Men. London and New York: Rutledge.

Munoz Bank, C. (2008) Race, Gender, and Shop-Floor Politics in Mexico and the United States. Ithaca and London: Cornell University Press.

Oh, S.J. (1983) 'The Living Conditions of Female Workers in Korea', Korea Observer 24(2):185200.

Ong, A. (1987) Spirits of Resistance and Capitalist Discipline: Factory Women in Malaysia. Albany: State University of New York Press.

Ong, A. (1988) 'Colonialism and Modernity: Feminist Re-presentations of Women in NonWestern Societies', Inscriptions 3: 79-93.

Ong, A. (1991) 'The Gender and Labour Politics of Postmodernity', Annual Review of Anthropology 20: 279-309.

Ozler, S. (2000) 'Export Orientation and Female Share of Employment: Evidence from Turkey', World Development 28(7): 1239-1248.

Parpart, J.L. (1993). "Who is the "Other"? A Postmodern Feminist Critique of Women and Development Theory and Practice', Development and Change 24(3): 439-464.

Pearson, R. (1991) 'Male Bias and Women's Work in Mexico's Border Industries', in E. Diane (ed) Male Bias in the Development Process (pp. 133-163). Manchester: Manchester University Press.

Pearson, R. (1995) 'Male Bias and Women's Work in Mexico's Border Industries' in D. Elson and R. Pearson (eds) Male Bias in the Development Process (pp. 133-166). Manchester and New York: Manchester University Press.

Phillips, A and Taylor, B. (1980) 'Sex and Skill: Notes Towards a Feminist Economics', Feminist Review 6: 79-88. 
Porpora, D.V., Lim, M.H. and Prommas, U. (1989) 'The Role of Women in the International Division of Labour: The Case of Thailand', Development and Change 20(2): 269-294.

Pred, A. (1990) 'In Other Wor(l)ds: Fragmented and Integrated Observations on Gendered Languages, Gendered Spaces and Local Transformation', Antipode 22(1): 33-52.

Pyle, J.L and Ward, K.B. (2003) 'Recasting our Understanding of Gender and Work During Global Restructuring', International Sociology 18(3): 461-489.

Ram, K. (1991) Mukkuvar Women: Gender, Hegemony and Capitalist Transformation in a South Indian Fishing Community. North Sydney: Allen and Unwin.

Rao, R. V. and Husain, S. (1991) 'Invisible Hands - The Women Behind India's Export Earnings', in N. Banerjee (ed) Indian Women in a Changing Industrial Scenario (pp. 133-200). New Delhi: Sage Publishers.

Safa, H.I. (1981). 'Runaway Shops and Female Employment: The Search for Cheap Labour'. Signs: Journal of Women in Culture and Society 7(2): 418-33.

Salzinger, L. (2000) 'Manufacturing Sexual Subjects: "Harassment", Desire and Discipline on a Maquiladora Shopfloor', Ethnography 1(1): 67-92.

Salzinger, L. (2003) Genders in Production: Making Workers in Mexico's Global Factories. California: University of California Press.

Schrijvers, J. (1993) 'Motherhood Experienced and Conceptualized: Changing Images in Sri Lanka and the Netherlands', in D. Bell, P. Caplan and W. Jahan Karim (eds) Gendered Fields: Women, Men and Ethnography (pp. 143-58). London: Rutledge.

Sharma, R.N. and Sengupta, C. (1984) 'Women Employment at SEEPZ, Bombay Mimeograph TISS', Report prepared for Indian Council for Research on International Economic Relations, New Delhi.

Soni-Sinha, U. (2006) 'Where are the Women? Gender, Labor and Discourse in Nodia Export Processing Zone and Delhi', Feminist Economics 12(3): 335-366.

Spivak, G.C. (1990) The Post Colonial Critic: Interviews, Strategies, Dialogues. S. Harasym (ed) New York: Routledge.

Standing, G. (1989) 'Global Feminization through Flexible Labour' World Development 17(7): 1077-95. 
Standing, G. (1999) 'Global Feminization through Flexible Labour: A Theme Revisited.' World Development 27(3): 583-602.

Sun, S.H. (1987) 'Women, Work and Theology in Korea', Journal of Feminist Studies 3(1/2): $125-134$.

Tiano, S. (1994) Patriarchy on the Line: Labour, Gender and Ideology in the Mexican Maquila Industry. Philedalphia: Temple University Press.

Wichterich, C. (2000). The Globalized Woman: Reports from a Future of Inequality. London and New York: Zed books.

Wilkinson-Weber, C.M. (1997) 'Skill, Dependency, and Differentiation: Artisans and Agents in the Lucknow Embroidery Industry', Ethnology 36(1): 49-65.

Wolf, D.L (1992) Factory Daughters: Gender, Household Dynamics, and Rural Industrialization in Java. Berkley: University of California Press.

Women Working Worldwide (1991) Women Organising in Global Electronics. London: Women Working Worldwide.

\section{BIOGRAPHICAL NOTE}

URVASHI SONI-SINHA is a postdoctoral fellow in Labour Studies at McMaster University in Canada. She has done her doctorate in Women and Gender Studies from University of Warwick, UK. Her thesis is entitled 'Gendered Labour Process and Flexibility: A Study of Jewellery Production in India'. Her research interests include women, gender and work, women and globalization, feminist methodologies, women and unions and gender, race and precarious employment. 


\section{APPENDIX}

Table A1: Profile of the workers and their job conditions

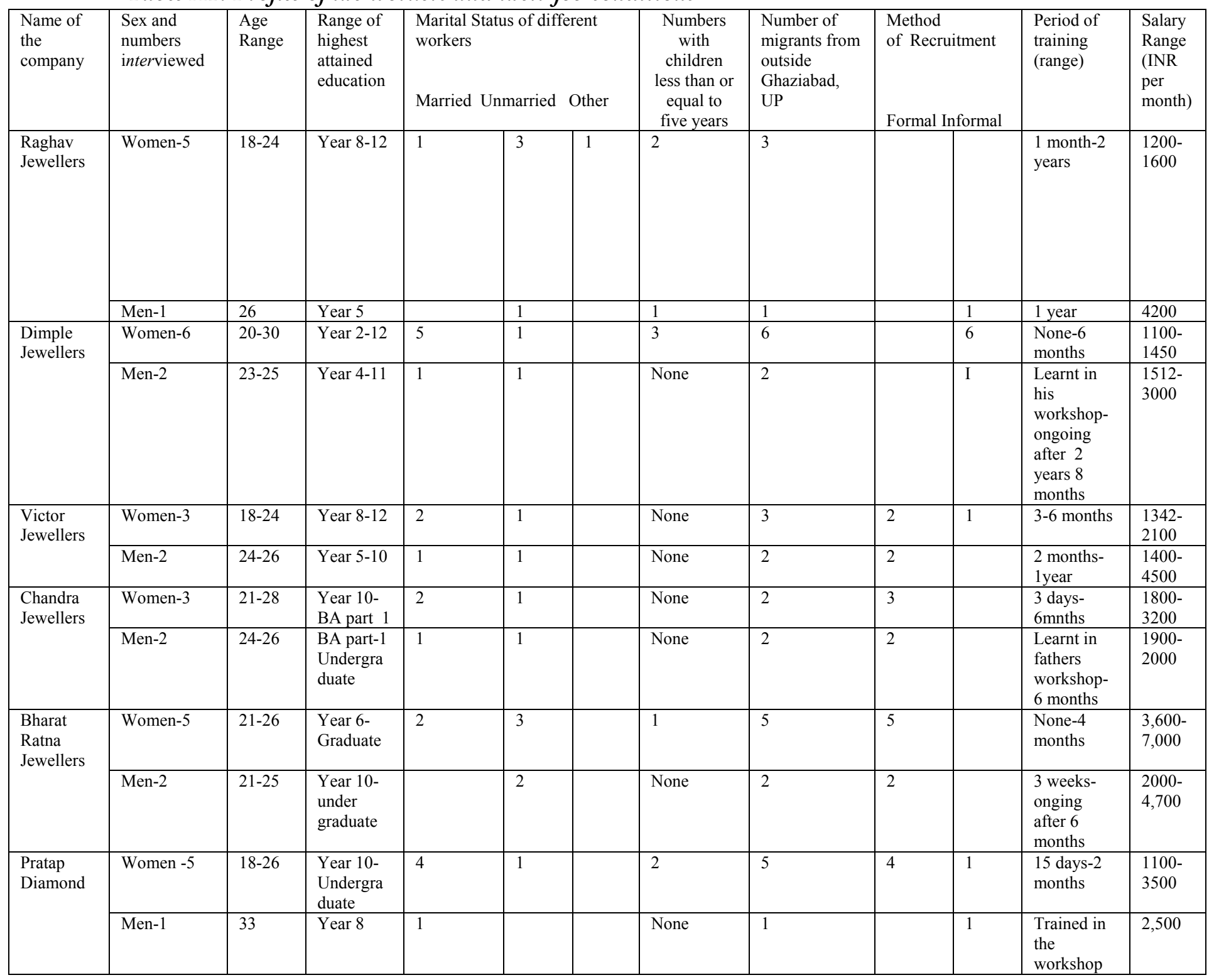

Source: Based on the interviews carried in NEPZ between May 1996 and January 1997 Index 